\section{Penurunan Stok Tegakan Alami Masohi [CRYPTOCARYA MASSOY (OKEN) KOSTERM] DI KABUPATEN NABIRE}

\author{
Julius Dwi Nugroho', Jimmy Frans Wanma², Cicilia Maria Erna Susanti², \\ Susilo Budi Husodo ${ }^{4}$, Nouke Lenda Mawikere ${ }^{5}$ \\ 1,2,3,4Fakultas Kehutanan Universitas Papua \\ ${ }^{5}$ Fakultas Pertanian Universitas Papua \\ Jl. Gn. Salju, Manokwari Barat, Amban, Manokwari, Papua Barat 98314
}

Dikirim: 1 Oktober 2019; Direvisi: 29 Oktober 2019; Disetujui: 18 Desember 2019

\begin{abstract}
Masohi [Cryptocarya massoy (Oken) Kosterm] belongs to Lauraceae family, which has a high economic value. This plant hasthe capacity to produce secondary metabolites that have potential as anti-cancer, anti-microbial, and flavor enhancer. Due to the high demand of Masohi bark for the market need, natural Masohi stands have been exploiting. This study aimed to analyze the condition of natural Masohistanding stock in Nabire through the identification of Masohi bark collected by the traders, Masohi bark shipping outside Nabire during 2012-2015 and tracking the availability of Masohi stands in its habitat. Interviews with key informants related to the bark harvesting and production and field surveys were conducted.The data reveals that Masohi bark production in Nabire reduced dramatically to 68\% in the period of 2012-2015. Most of the production came from young plants (56\%) with adiameter of $<18 \mathrm{~cm}$. It was indicated that declining of Masohi natural standing stock has occurred in Nabire. Therefore, plantation development action of Masohi plantson a large scale is urgently needed.
\end{abstract}

Keywords: masohi, cryptocarya massoy, Nabire, standing stock, reduction in masohi bark stock

Intisari

Masohi [Cryptocarya massoy (Oken) Kosterm.] tergolong dalam famili Lauraceae yang memiliki nilai ekonomi tinggi. Tanaman ini menghasilkan metabolit sekunder yang berpotensi untuk dijadikan antikanker, antimikroba dan peningkat rasa. Eksploitasi tegakan alam Masohi untuk diambil kulitnya telah lama dilakukan karena harga yang tinggi. Penelitian ini bertujuan untuk menganalisis kondisi stok tegakan alamiMasohi di Nabire melalui identifikasi kulit kayu yang dikumpulkan oleh pedagang pengumpul ke luar Nabire pada periode 2012-2015 dan menelusuri keberadaan tegakan alami Masohi di habitatnya. Interview terhadap informan kunci yang bersangkutpaut dengan aktivitas pengambilan kulit kayu Masohi dan survey lapangan dilakukan untuk tujuan tersebut. Data yang diperoleh mengungkapkan bahwa produksi kulit kayu kayu Masohi turun secara dramatis yaitu hingga 68\% dalam periode 2012 -2015. Produksi kulit kayu sebagian besar terlacak berasal dari pohon muda (56\%) berdiameter $<18 \mathrm{~cm}$. Hal ini mengindikasikan telah terjadi penurunan stok tegakan Masohi alam di Nabire. Oleh karena itu pengembangan penanaman Masohi dalam skala besar sangat dibutuhkan.

Kata Kunci: masohi, cryptocarya massoy, Nabire, standing stock, penurunan stok tegakan

\section{LATAR BELAKANG}

Masohi [Cryptocarya massoy (Oken) Kosterm] termasuk dalam famili Lauraceae, yang secara geografi menyebar daerah tropis, New Guinea, Queensland, dan Australia. Jenis ini merupakan salah satu jenis tumbuhan berkayu yang berharga untuk diambil kulitnya. Pengambilan kulit kayu Masohi secara alami di hutan telah dilakukan sejak abab 17 (Westphal \& Jansen, 1989).
Tumbuhan Masohi menghasilkan metabolit sekunder yang memiliki nilai ekonomi tinggi baik yang terkandung dalam buah, kayu maupun kulit kayunya. Secara tradisional ekstrak kulit kayu Masohi telah umum digunakan sebagai minyak gosok bagi penyembuhan pegal otot dan sakit kepala. Kegunaan lain ekstrak kulit kayu Masohi adalah untuk mengobati sakit demam, diare dan pemulihan setelah melahirkan (Westphal

\footnotetext{
* Korespondensi Penulis

Phone : +6281282867302

Email : jd.nugroho2014@gmail.com
}

(C) 2019 Julius Dwi Nugroho, Jimmy Frans Wanma, 
\& Jansen, 1989). Dilaporkan pula kulit kayu Masohi telah dikenal oleh masyarakan lokal sebagai obat tradisional bagi penyakit tuberculosis, pneumonia, bronchitis dan penyakit infeksi pada umumnya dan untuk mengobati gigitanular (Erari, 2005; Pasapan, 2005; Putra, 2003).

Hasil distilasi air terhadap kulit, kayu dan buah C. massoia yang dilakukan oleh Rali, Wossa dan Leach (2007) diperoleh minyak atsiri (essential oil) berwarna kuning dengan hasil rendemen berturut-turut dari kulit kayu 0,7\%, kayu (batang) 1,2\% dan buah 1,0\%. Komponen utama kima dari minyak Masohi berupa senyawa C-10 (5,6-dihydro-6-pentyl2H-pyron-2-one) dan C-12 (5,6-dihydro-6heptyl-2H-pyron-2-one) massoia-lactone. Untuk minyak dari kulit kayu terkandung pula sejumlah kecil senyawa C-14 (5,6-dihydro6-nonyl-2H-pyron-2-one) massoia lactone $(1,4 \%)$. Untuk minyak dari kayu mengandung senyawa C-10 jenuh derivative decalacton. Sementara minyak asal buah mengandung komponen utama benzyl benzoate $(68,3 \%)$.

Lebih lanjut, Triatmoko, Hertiani dan Yuswanto (2016) melaporkan bahwa minyak Masohi memiliki kemampuan aktivitas cytotoxic melawan Vero cell dengan $\mathrm{IC}_{50}$ pada $97,4 \mu \mathrm{g} / \mathrm{ml}$. Hal ini berarti bahwa minyak Masohi memiliki potensi sebagai anti-microba and anti-cancer. Cytotoxicity berkaitan dengan kandungan senyawa masoi-lactone yang terdapat dalam minyak Masohi. Selain masoi-lactone, terdapat pula kandungan senyawa ester dari $\delta$-decalactone yang dapat dipergunakan pada industri makanan dan flavor, khususnya untuk aroma coconut creamy peach (Schneiderman et al., 2014). Sampai saat ini, banyak penelitian pemanfaatan jenis ini masih dilakukan secara intensif yang akan menghasilkan bertambahnya penemuan baru untuk mendukung pemanfaatan yang lebih luas dalam industri. Konsekuensi dari penemuanpenemuan tersebut akan terus meningkatkan nilai ekonomi Masohi yang juga secara langsung akan mendorong kebutuhan akan material Masohi dari tahun ke tahun.

Aktivitas pemanenan Masohi di Papuatelah berjalan sangat lama dengan saat puncaknya terjadi pada tahun 1990-an bersamaan dengan aktivitas pemanenan Gaharu. Pengambilan kulit Masohi delakukan dengan cara menebang pohon sehingga praktis akan mengganggu permudaan alami bila penebangan tidak terkontrol. Dengan waktu yang telah berjalan demikian lamanya dalam eksploitasi kulit kayu Masohi, menimbulkan pertanyaan bagaimana kondisi stok Masohi di alam dalam mendukung kebutuhan di masa mendatang. Penelitian ini bertujuan untuk mengetahui stok tumbuhan Masohi di alam pada kawasan hutan di Kabupaten Nabire.

\section{Metode}

\section{a) Lokasi Penelitian}

Kabupaten Nabire dipilih sebagai lokasi penelitian karena sebagian pasokan kulit Masohi asal Papua berasal dari kabupaten ini. Kabupaten ini merupakan salah satu Kabupaten di Provinsi Papua yang secara geografi terletak pada garis lintang $134^{\circ} 33^{\prime \prime}-136^{\circ} 15^{\prime \prime}$ BT dan $134^{\circ} 33^{\prime \prime}$ - 136 15" LS (Gambar 1).

Survei lapangan untuk menelusuri keberadaan tegakan Masohi di alam dilakukan dengan menyusuri Sungai Poronai dan plotplot pengamatan didirikan di daerah Kampung Kew pada lokasi habitat tegakanMasohi sesuai dengan petunjuk masyarakat pengumpul kulitkayu Masohi.

\section{b) Produksi Kulit Masohi}

Produksi kulit Masohi dari Kabupeten Nabire diperoleh dari data pengiriman kulit Masohi ke luar Kabupaten Manokwari melalui pelabuhan pada periode 2012-2015 yang diperoleh dari Dinas Kehutanan Kabupaten Nabire yang mempunyai kewenangan untuk menerbitkan pengiriman hasil hutan secara legal. Data selanjutnya diolah untuk mendapatkan gambaran kecenderungan produksi kulit Masohi selama ini.

Pengukuran kulit kayu Masohi kering yang dikumpulkan oleh pedagang pengumpul di Kabupeten Nabire dilakukan untuk menelusuri kecenderungan penebangan tegakan alami Masohi pada kelas diameter berapa. Contoh kulit kayu kering diambil secara acak dari pedagang pengumpul yang masih operasional di Kabupeten Manokwari. Keseluruhan contoh kulit kayu Masohi kering dijadikan contoh komposit dan selanjutnya diukur ketebalan kulit kayu kering. Data selanjutnya diolah menggunakan statistik deskriptif untuk memperlihatkan rataan, range dan standar deviasi. Data tersebut merupakan data indikatif 


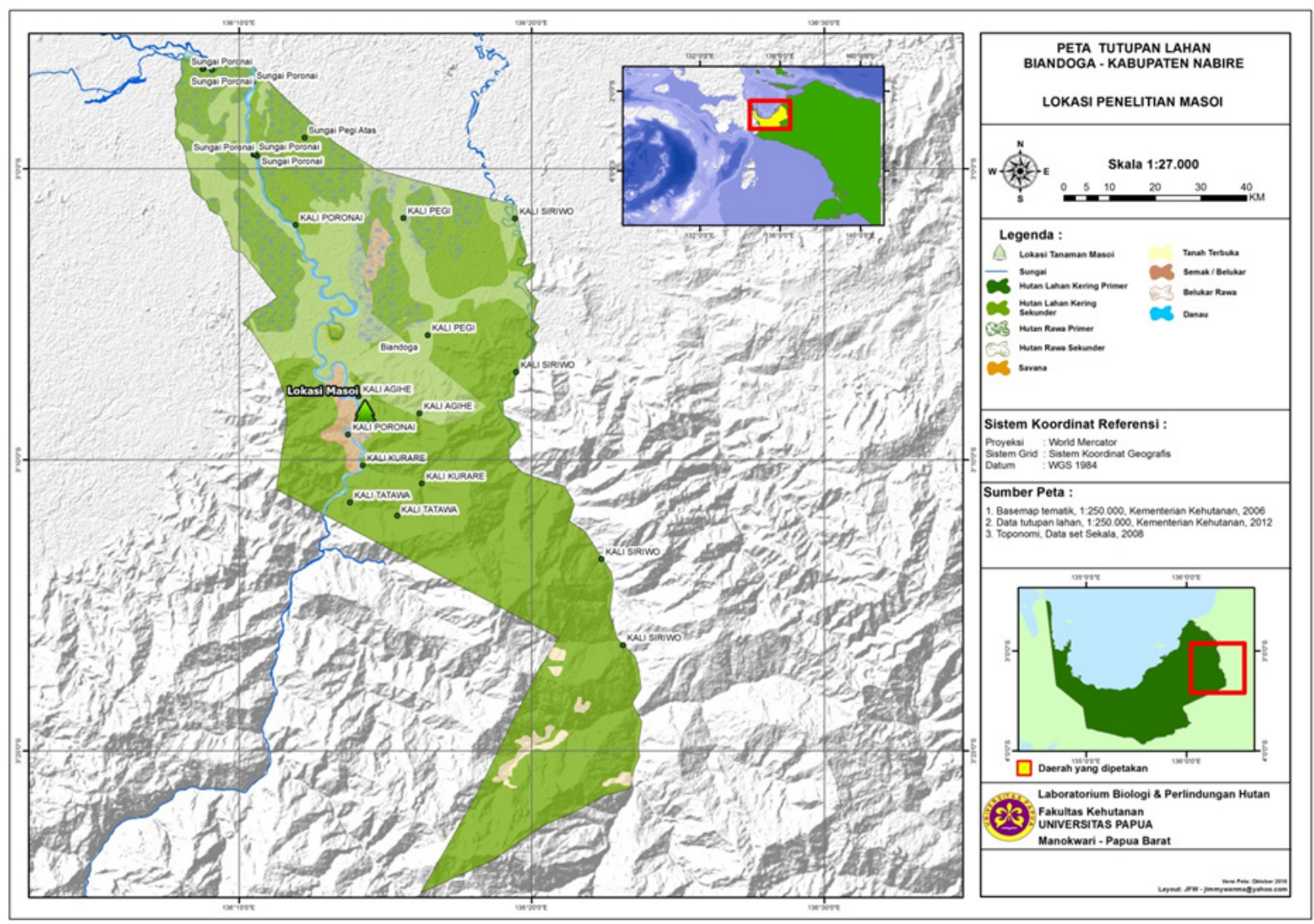

Gambar 1. Peta Kabupaten Nabire dan Lokasi Survey Tegakan Alami Kayu Masohi di Sepanjang S. Poronai

untuk pendugaan kelas diameter tegakan yang ditebang saat ini dengan membandingkan tebal kulit kayu segar dan nilai penyusutannya.

Ketebalan kulit kayu kayu segar diperoleh dari cuplikan pohon yang dijumpai di lapangan baik dari hutan alam maupun tanaman di Kabupaten Nabire. Bersamaan dengan pengambilan cuplikan kulit kayu segar diambil pula diameter pohon setinggi dada. Pendugaan hubungan antara ketebalan kulit kayu Masohi segar (y) dengan diameter pohon Masohi (x).

Ketebalan kulit kayu Masohi kering selanjutnya dapat diubah menjadi ketebalan kulit kayu segar dengan mempertimbangkan nilai penyusutan kulit kayu Masohi saat pengeringan. Dengan diketahui tebal kulit segar maka dapat diduga seberapa besar diameter pohon yang ditebang dapat melalui persamaan regresi yang diperoleh.

Nilai penyusutan kayu Masohi diperoleh melalui pendekatan asumsi. Berdasarkan penelitian Istikowati et al. (2015) pada kayu manis(Cinnamomum sp.) diketahui penyusutan kayu arah tangensial per kadar air 1\% sebesar $0.28 \%$. Berdasarkan wawancara terhadap pengumpul kayu kulit Masohi mendapat gambaran bahwa kulit kayu segar yang kemudian dikeringkan akan kehilangan bobot hingga separuhnya atau 50\% kehilangan air. Dengan demikian maka nilai penyusutan yang akan digunakan untuk mengkonversi tebal kulit kayu segar ke kulit kayu keringadalah 0,28 $\mathrm{x} 50=14 \%$.

\section{c) Stok Tegakan Alami}

Ketersediaan stok tegakan alami di hutan diidentifikasi melalui interview menggunakan daftar pertanyaan terbuka terhadap informan kunci meliputi pencari kulit kayu Masohi, kepala kampung dan pengumpul/pedagang kulit kayu Masohi. Pengecekan di lapangan dilakukan dengan teknik survei melalui penelusuran $S$. Poronai dengan dipandu oleh pencari kulit kayu Masohi. Penjelajahan dilakukan pada habitat tegakan Masohi di daerah Kampung Kew dan setiap pertemuan dengan tegakan Masohi atau bekas tebangan Masohi maka pengamatan dilakukan dengan memfokuskan terhadap keberadaan tegakan Masohi. 


\section{HASIl DAN PEMBahSAN}

\section{A. Produksi Kulit Masohi di Kabupaten Nabire}

Data produksi yang diperoleh dari Dinas Kehutanan dan Perkebunan Kabupaten Nabire merupakan data rekaman jumlah perusahaan/pengusaha yang memiliki izin pengumpulan dan pengiriman kayu Masohi dan data pengiriman legal yang dilakukan oleh pengusaha pengumpul kulit kayu Masohidari tahun 2012-2015 (Gambar 2). Dari rekaman data tampak bahwa dari 4 perusahaan yang operasional dan memiliki izin pengumpulan dan pengiriman kulit kayu Masohi dari tiga perusahaan yang memiliki izin pada tahun 2012, pada tahun 2013 hanya dua perusahaan yang aktif, sedangkan pada tahun 2015 tinggal satu perusahaan yang aktif yaitu CV. Kirana Setia. Penurunan perusahaan pengumpul yang aktif, dibarengi pula dengan penurunan jumlah kulit Masohi yang mampu dikumpulkan. CV. Kirana Setia pada tahun 2012 mampu mengumpulkan dan mengirimkan ke luar kabupaten Nabire sebesar $40.000 \mathrm{~kg} /$ tahun menurun drastis menjadi separuhnya saja yaitu $20.950 \mathrm{~kg} /$ tahun. Demikian pula total kulit kayu Masohi yang dikirim ke luar Nabire menurun sangat mencolok dari total 66.000 $\mathrm{kg} /$ tahun menjadi hanya $20.950 \mathrm{~kg} /$ tahun atau turun sebesar $68 \%$. Berdasarkan wawancara terhadap otoritas yang menangani komoditi kulit kayu Masohi dan pengusaha yang terlibat langsung dalam pengumpulan dan pengiriman kulit Masohi, kesulitan dalam memenuhi kuota pengiriman yang diberikan lebih disebabkan oleh sulitnya mendapat stock kulit kayu segar dari pengumpul dari lapangan (masyarakat).

Pengukuran serpihan kulit kayu Masohi kering berasal dari pedagang/pengusaha pengumpul memperlihatkan adanya rentang keragaman yang cukup besar dari serpihan yang sangat tipis $\left(1,48-3,98 \mathrm{~cm} ; S^{2}=0,50 \mathrm{~cm}\right)$ hingga tebal $\left(6,48-8,88 \mathrm{~cm} ; S^{2}=0,69 \mathrm{~cm}\right)$. Jumlah terbesar merupakan serpihan dengan rentang ketebalan 1,48-3,98 cm (335 serpihan atau sebesar $56 \%$ dari total serpihan) disusul dengan rentang ketebalan 3,98-6,48 cm (249 serpihan) dan terkecil pada rentang ketebalan 6,48-8,88 cm (16 serpihan) (Tabel 1).

Terdapat hubungan linier yang erat antara ketebalan kulit kayu segar dan diameter kulit kayu Masohi. Semakin besar diameter pohon Masohi (x) semakin tebal pula kulit

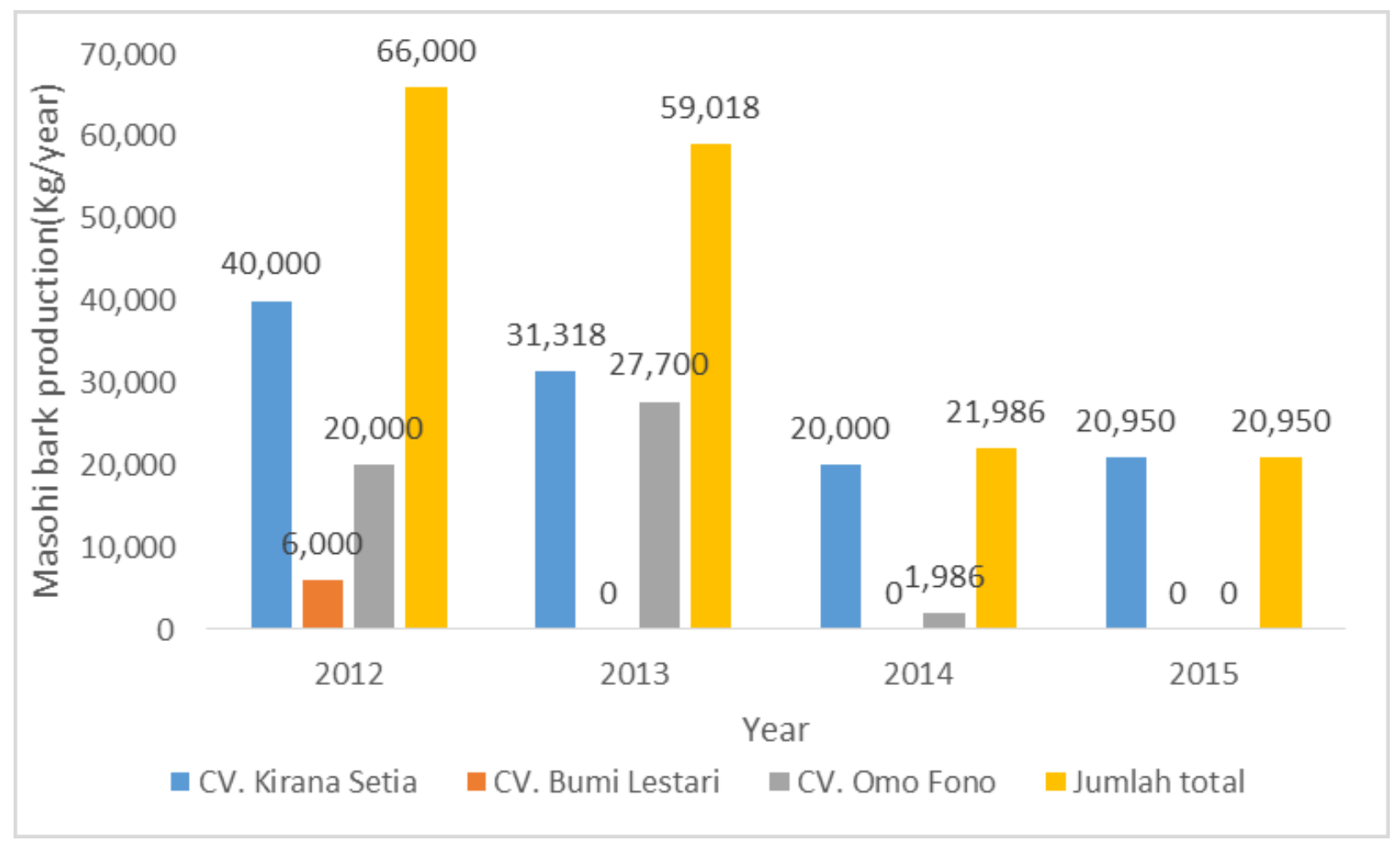

Gambar 2. Perusahaan Pengumpul Berizin dan Produksi Kulitmasohi Kering dari Tahun 2012-2015 di Kabupaten Nabire 
Tabel 1.

Statistik Diskripsi Ketebalan Kulit Kayu Masohi Kering Udara yang Dikumpulkan Pengusaha Pengumpul Kulit Kayu Masohi pada Tahun 2015

\begin{tabular}{ccc}
\hline \multicolumn{3}{c}{ Rentang Ketebalan Kulit Kayu Masohi Kering Udara (mm) } \\
\hline $1,48-3,98$ & Rata-rata Ketebalan Kulit Kayu Masohi Kering Udara (cm) \\
\hline 3.23 & $4,84,88$ \\
\hline \multicolumn{3}{c}{ Standar DeviasiKetebalan Kulit Kayu Masohi Kering Udara (cm) } \\
\hline 30 & 0,65 & 0,69 \\
\hline 335 & Jumlah Serpihan Kulit Masohi Kering Udara yang Diukur (n) \\
\hline
\end{tabular}

kayu Masohi (y), yang digambarkan dengan persamaan regresi linier $y=1,1070+0,2193 x$ dan nilai korelasi sebesar 0,71 (Gambar 2)

Serpihan kulit kayu kering Masohi kelas tertipis $(1,48-3,98 \mathrm{~mm})$ pada pencuplikan contoh dari stok pada pedagang/pengusaha pengumpul yang selanjutnya ditimbang dengan nilai penyusutan kulit kayu sebesar $14 \%$, maka diperoleh ketebalan kulit kayu segar sebesar 1,72- 4,62 mm yang diperkirakan berasal dari pohon atau batang yang berdiameter antara 2,79-16,02 cm. Sedangkan kelas serpihan tebal kulit kayu kering tertebal $(6,48-8,80 \mathrm{~mm})$ setara dengan tebal kulit kayu segar sebesar
7,53 - 10,33 mm, yang diperkirakan berasal dari pohon atau batang berdiameter 29.28 $42,06 \mathrm{~cm}$.

\section{B. Kondisi Stok Tegakan di Alam}

Dari hasil survei, sulit lagi ditemukan tegakan alami utuh. Hanya tertinggal beberapa beberapa hasil permudaan yang terpencar di antara bekas tebangan. Tidak dijumpai adanya pohon dewasa bahkan tingkat tiang sekalipun. Diperkirakan kerapatan regenerasi sisa sekitar 16 pancang/ha dan 20 anakan/ ha yang umumnya terdapat pada tempat

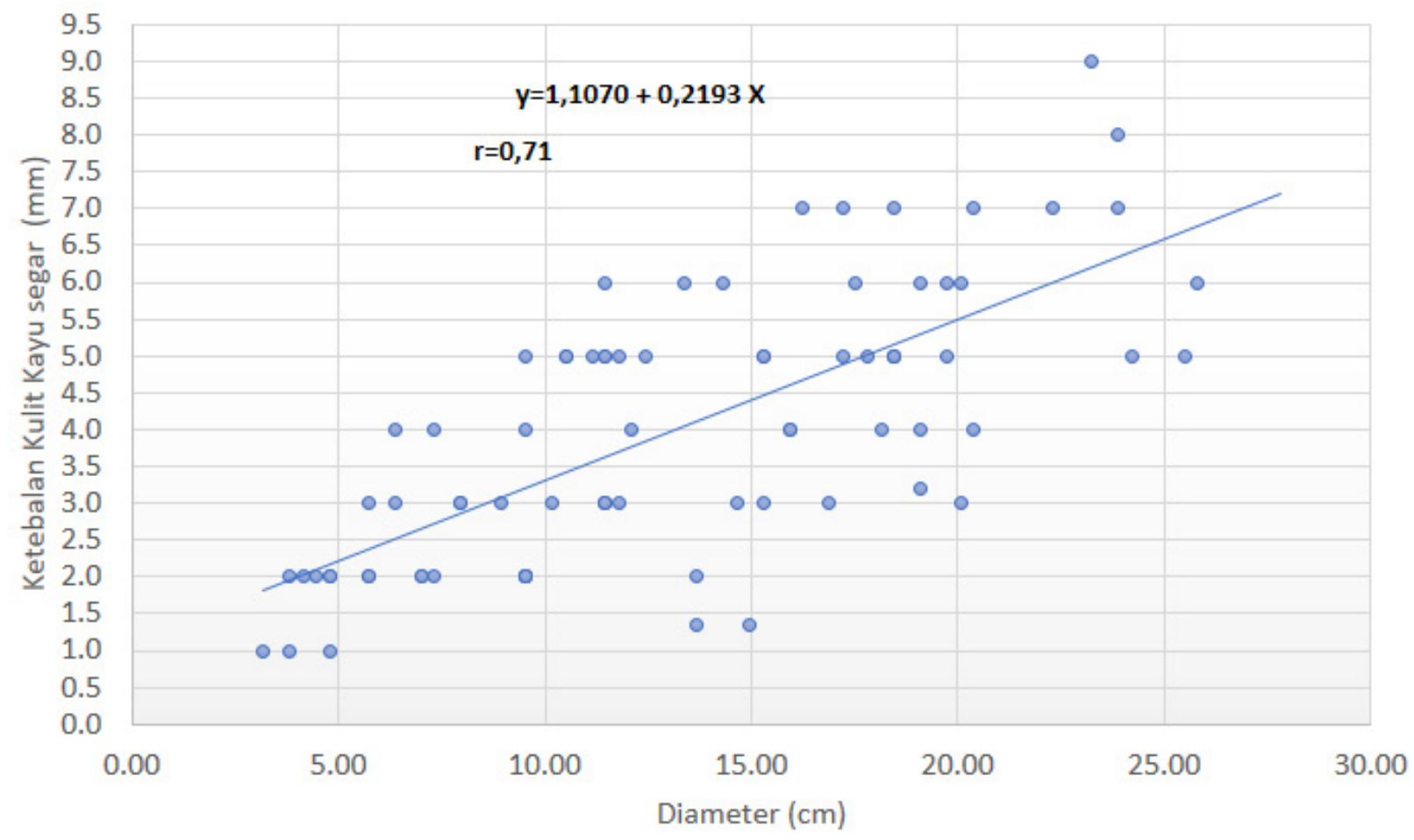

Gambar 3. Regresi Hubungan antara Diameter Pohon (cm) dan Ketebalan Kulit Kayu Masohi Segar 
berlereng yang tersebar di sekitar tunggak pohon bekas tebangan. Tunggak-tunggak Masohi bekas tebangan dijumpai ada yang mampu menghasilkan trubusan kembali. Dijumpai pula bekas-bekas batang yang telah diambil kulitnya. Pada umumnya dari tunggak bekas tebangan maupun batang bekas dikuliti memiliki diameter antara 15-20 cm (Gambar 4)

Data produksi kulit kayu Masohi kering dan jumlah perusahaanberizinyangmengumpulkan dan mengirim kulit kayu Masohi ke luar Kabupaten Nabire dari tahun 2012-2015 telah memperlihatkan terjadinya penurunanyang tajam pasokan kulit Masohihasil pemanenan dari hutan alam yang berhasil dikumpulkan para pengumpul kulit kayu, yaitu penurunan sebesar 68\%. Kondisi kekurangan pasokan kulit kayu Masohi telah menjadi keluhan utama bagi pengusaha pengumpul kulit kayu Masohi di Nabire sehingga mereka tidak mampu untuk memenuhi kuota pengiriman sesuai dengan izinyang diberikan.

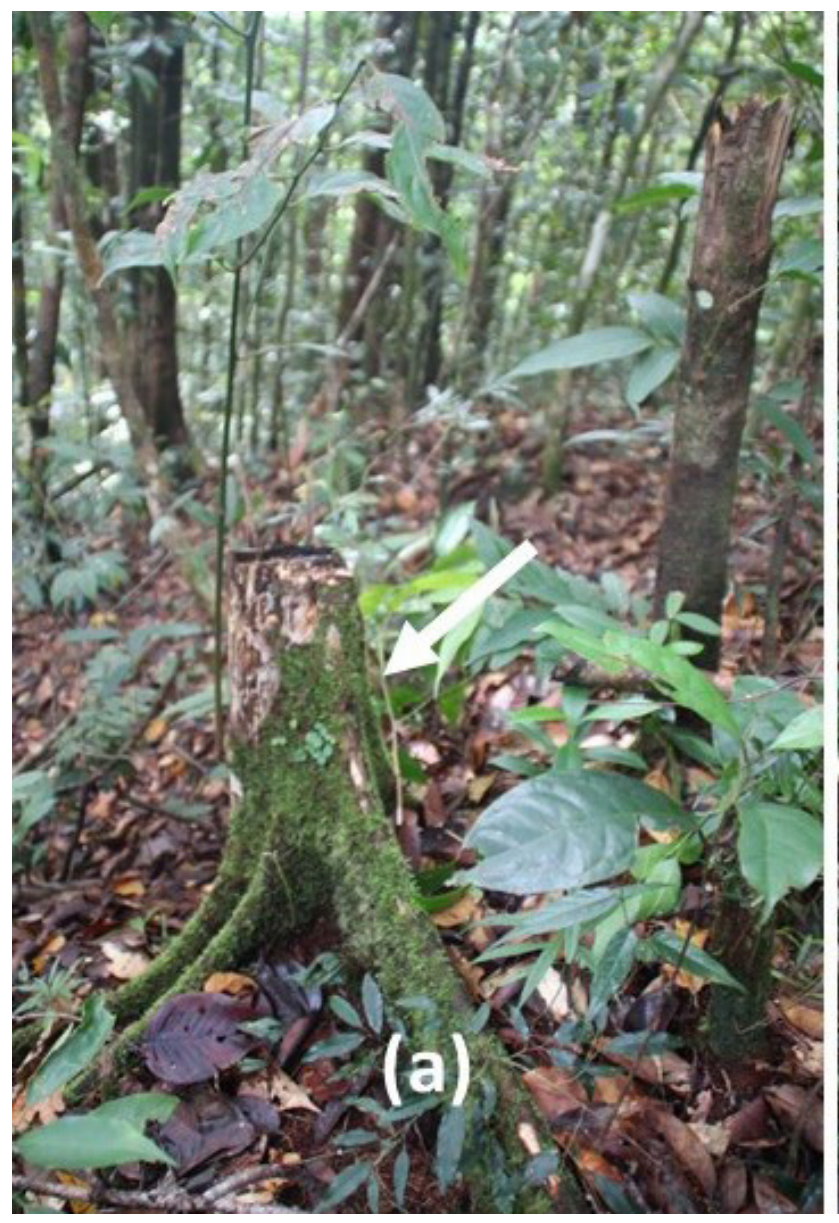

Berdasarkan serpihan kulit kayu kering asal pengusaha pengumpul kulit kayu Masohi mengindikasikan bahwa pohon atau batang yang ditebang dan dikuliti diprediksi berdiameter $2,79 \mathrm{~cm}$ dan terbesar berdiameter $42,06 \mathrm{~cm}$, dengan kecenderungan penebangan pada pohon atau batang terbanyak (56\%) terjadi pada kelas diameter kecil (2,79-16,02 $\mathrm{cm})$. Hasil ini sejalan dengan penelitian dari Luamasar (2010) di Kabupaten Kaimana, yang menyatakan bahwa penebangan pohon kayu Masohi dilakukan pada rentang pohon berdiameter 21 - $58 \mathrm{~cm}$. Penurunan kelas diameter pohon yang ditebang juga sejalan dengan pernyataan pencari kulit kayu Masohi yang menyatakan bahwa penebangan tidak saja dilakukan pada pohon berdiameter besar tetapi juga pada pohon diameter kecil, yang penting batang pohon tersebut sudah mudah dikuliti. Pohon yang mudah dikuliti biasanya memiliki diameter sekitar $15 \mathrm{~cm}$.

Dugaan penebangan pohon Masohi

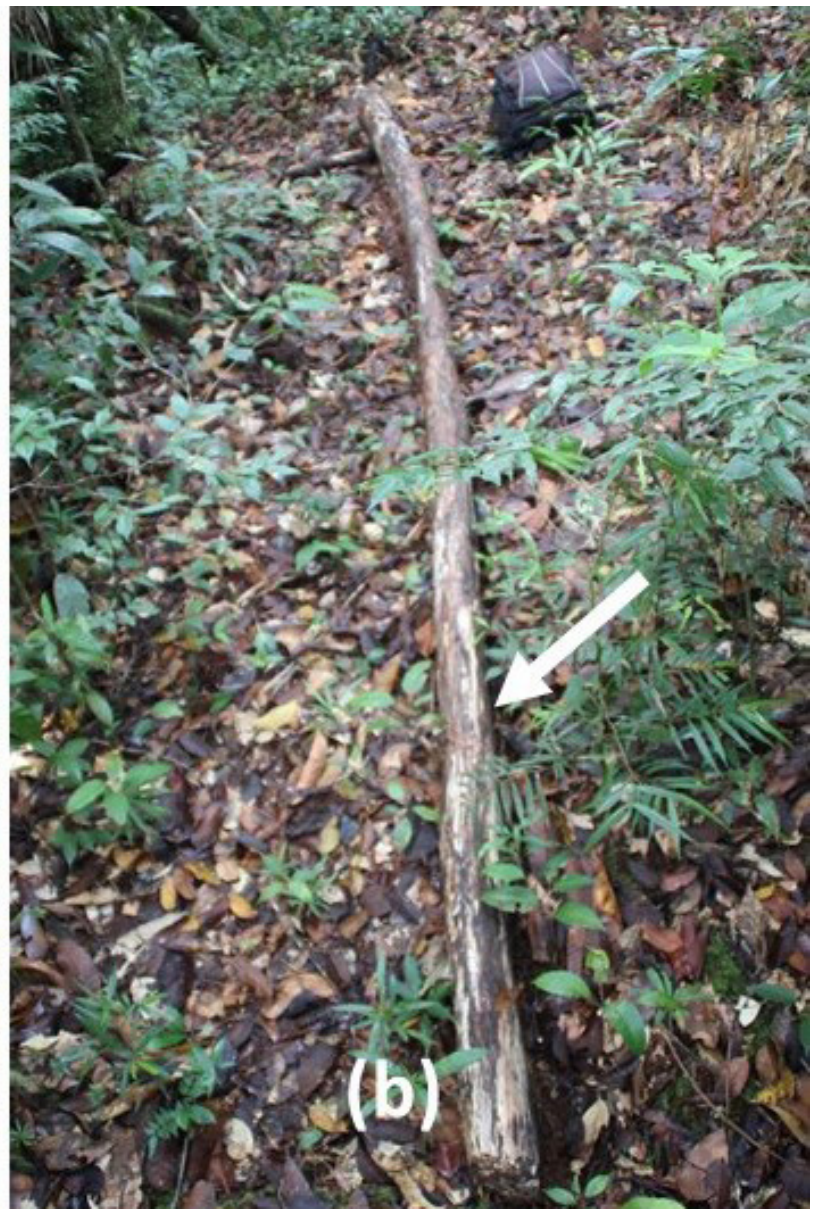

Gambar 4. Bekas tebangan Masohi.

(a) Tunggak Bekas Tebangan dengan Trubusannya; (b) Batang yang Ditinggalkan Berukuran 15 cm Setelah Dikupas untuk Diambil Kulitnya. 
telah dilakukan pada pohon-pohon dengan diameter kecil merupakan fakta di lapangan. Penelusuran yang dilakukan di daerah habitat tumbuh kayu Masohi, ternyata telah sulit untuk menemukan tegakan yang masih utuh. Tegakan Masohi semakin jauh untuk dijangkau dan seluruh tegakan yang dijumpai hanya tinggal dalam bentuk tunggak bekas tebangan dengan sedikit permudaan yang ada di dalamnya. Dari tunggak dan batang yang ditinggalkan setelah penebangan dan pengulitan juga memperkuat bahwa memang penembangan telah dilakukan pada pohon Masohi dengan diameter batang kecil yaitu antara $15-20 \mathrm{~cm}$.

Kondisi demikian merupakan peringatan bahwa perburuan dan pemanenan kulit kayu Masohi telah pada batas yang membahayakan untuk kelestariannya. Tegakan-tegakan Masohi alami yang mudah dijangkau akan menjadi sasaran dan karena kelangkaan tegakan alami yang utuh dan berdiameter besar, maka pohonpohon dengan diameter kecil pun menjadi sasaran. Regenerasi yang terjadi tidak seberapa banyak, tidak akan memiliki kesempatan untuk bertumbuh menjadi dewasa dan menghasilkan propagul untuk menunjang regenerasi berikutnya, karena akan ditebang saat sudah bisa dikuliti.

Kebijakan pembatasan produksi kulit kayu Masohialami perlu dilakukan dibarengi dengan usaha pembudidayaan Masohi dalam menjawab kebutuhan untuk produksi dan usaha konservasi ex-situ. Pengembangan pengetahuan pembudidayaan dan teknik pemanenan yang lebih menjamin kelestarian perlu mendapat perhatian. Demikian pula pemanfaatan bagian lain dari pohon selain kulit kayu perlu dikaji untuk dapat diserap oleh industri sehingga pemanenan Masohi tidak hanya bergantung pada kulit kayu sebagaimana diketahui bahwa tidak hanya kulit kayu yang mengandung massoia-lakton (Rali et al., 2007).

\section{KESIMPULAN}

Kesimpulan yang dapat diambil dari penelitian ini adalah:

1) Produksi kulit kayu kering Masohi di Kabupaten Nabire menurun drastis dari tahun 2012 - 2015 yaitu sebesar 68\%

2) Penebangan pohon Masohi sebesar $56 \%$ telah menyasar ke pohon-pohon berdiameter kecil $(.>16 \mathrm{~cm})$
3) Pembudidayaan Masohi merupakan suatu kebutuhan yang mendesak sebagai suatu tindakan konservasi ex-situ

4) Pengembangan pengetahuan pembudidayaan, teknik pemanenan dan pemanfaatan bagian-bagian lain dari pohon Masohi perlu dilakukan.

\section{UCAPAN TERIMA KASIH}

Penelitian ini dibiayai oleh Kementerian Riset, Teknologi dan Pendidikan Tinggi melalui skema Penelitian Unggulan Perguruan Tinggi Tahun 2016. Penulis juga mengucapkan terima kasih kepada Masyarakat Kampung Kew dan P. Ratewi, Nabire atas akses dan izin yang diberikan untuk dapat mencapai daerahdaerah penelitian. Ucapan terima kasih juga disampaikan kepada pimpinan CV. Kirana Setiap atas pemberian contoh kulit kayu Masohi dan Kepala Dinas Kehutanan dan Perkebunan Kabupaten Nabire atas izin penelitian dan pemberian data-data penelitian.

\section{Daftar Pustaka}

Erari, Y. (2005). Pemanfaatan Tumbuhan Secara Tradisional oleh Masyarakat Suku Wate di Kampung Nifasi Distrik Napan Kabupaten Nabire. Universitas Papua.

Istikowati, W., Aiso, H., Ishiguri, F., Sutiya, B., Lizuka, K., \& Yokota, S. (2015). Wood Properties of Kayu Manis (Cinnamomum sp.) Planted in South Kalimantan, Indonesia. BulletinofThe Utsunomiya University Forest, 51(April), 19. https://www.researchgate. net/publication/290438729_Wood_ properties_of_kayu_manis_Cinnamomum_ sp_planted_in_South_Kalimantan_ Indonesia/citation/download

Luanmasar. (2010). Hubungan Diameter Pohon terhadap Produksi Kulit Masoi (Cryptocarya Massoi) pada Hutan Lindung Tanggaromi Kabupaten Kaimana. Universitas Papua.

Pasapan, E. (2005). Pemanfaatan Tumbuhan sebagai Obat Tradisional dan Bahan Baku Benda Seni Budaya pada Etnik Moile di Kampung Anggra dan Simerbei Distrik Minyambouw Kabupaten Manokwari. Universitas Papua.

Putra, R. (2003). Jenis-Jenis Tumbuhan Obat Tradisional dan Pemanfaatannya Menurut Pengetahuan Lokal Masyarakat Suku Wamesa di Kampung Isenebuai Distrik 
Ransiki Kabupaten Manokwari. Universitas Papua.

Rali, T., Wossa, S., \& Leach, D. (2007). Comparative Chemical Analysis of the Essential Oil Constituents in the Bark, Heartwood and Fruits of Cryptocarya massoy (Oken) Kosterm. (Lauraceae) from Papua New Guinea. Molecules, 12(2), 149154. https://doi.org/10.3390/12020149

Schneiderman, D. K., Gilmer, C., Wentzel, M. T., Martello, M. T., Kubo, T., \& Wissinger, J. E. (2014). Sustainable Polymers in the Organic Chemistry Laboratory: Synthesis and Characterization of a Renewable
Polymer from $\delta$-Decalactone and l-Lactide. Journal of Chemical Education, 91(1), 131135. https://doi.org/10.1021/ed400185u Triatmoko, B., Hertiani, T., \& Yuswanto, A. (2016). Sitotoksisitas Minyak Mesoyi (Cryptocarya massoy) terhadap Sel Vero (Cytotoxicity of Mesoyi Oil (Cryptocarya massoy) on Vero Cell Lines). Pustaka Kesehatan, 4(2), 263266. https://jurnal.unej.ac.id/index.php/ JPK/article/view/3045

Westphal, E., \& Jansen, P. C. M. (1989). Plant resources of South-East Asia : a selection. Pudoc. 